\title{
Inhibitory Activity of Indonesian Soybean in comparison with Soybean Meal on Goblet Cell Count and Micro Vessel Density in Colitis-Associated Mouse Colon Carcinogenesis
}

\author{
Astra Suryani Putri ${ }^{1 \star}$, Kusmardi $^{2}$, Berna Elya ${ }^{1}$ \\ 'Department of Herbal, Faculty of Pharmacy, University of Indonesia, Depok, West \\ Java 16424. \\ ${ }^{2}$ Department of Pathology Anatomy, Faculty of medicine, University of Indonesia, \\ Salemba Raya, Jakarta 10430.
}

\begin{abstract}
Colon cancer is a major public health problem throughout the worldwide. Recently, many studies have focused on finding chemoprevention based on the natural compound. The present study was aimed to investigate the inhibitory activity of Indonesian soybean in comparison with soybean meal extract in colitis-associated mouse colon carcinogenesis.

Methods: In this study, Swiss Webster mice were induced by azoxymethane $10 \mathrm{mg} / \mathrm{kg}$ body weight followed by administration of $2 \%$ dextran sodium sulfate during a week. Soybean, soybean meal extract at each dose of 75,150 , and $200 \mathrm{mg}$ daily and aspirin $0,39 \mathrm{mg} / \mathrm{kg}$ body weight daily (equivalent to $150 \mathrm{mg}$ for a $70 \mathrm{~kg}$ human) administered orally. Histopathological examination of the colon tissue (hematoxylin-eosin staining) was done by counting the number of goblet cells and micro vessel density in ten randomly selected fields visual.

The results: Soybean and soybean meal significantly reduced the count of goblet cell $(\mathrm{P}<0,05)$ in colitis-associated colon carcinogenesis mice. Soybean extract is also significantly reduced the number of micro vessel density $(\mathrm{P}<0,001)$ in colitis-associated colon carcinogenesis mice. Otherwise, there were no significant effects of the soybean meal extract on the number of micro vessel density in colitis-associated colon carcinogenesis mice.

Conclusion: Our results indicate that Indonesian soybean and soybean meal extract may have inhibitory activity in colitis-associated colon carcinogenesis through inhibiting reduction in the number of goblet cell and micro vessel density. Indonesian soybean may have Inhibitory activity better than soybean meal.
\end{abstract}

Keywords : Colitis-associated colon carcinogenesis, soybean, soybean meal, lunasin, Azoxymethane, Dextran Sodium Sulfate.

\section{Introduction}

Colorectal cancer is a major public health problem throughout the worldwide ${ }^{1}$. Currently available therapies for cancer have serious side effects because of their low selectivity and specifity so that increase attention has been focused on chemoprevention ${ }^{2}$. 
Chemoprevention is a promising strategy for preventing cancer or inhibit the process of colon carcinogenesis. Many studies are being done to find chemopreventive agents from natural materials that have been known to contain large amounts of bioactive phytochemical components that can provide health benefits, especially for the fight against cancer ${ }^{3}$. Soybean $($ Glycine $\max \mathrm{L})$ known contains the bioactive peptide that has been shown to have anti-carcinogenic effects ${ }^{3-7}$. The grains of Glycine max belonging to the family Fabaceae are commonly known as 'kedelai' in Indonesia ${ }^{8}$. Epidemiological studies have shown that the association between the consumption of soy or soy products with reduced risk of colorectal cancer ${ }^{9-11}$. Soybeans contain a variety of phytochemicals, which demonstrated anticancer activity, including isoflavone ${ }^{12}$, protease inhibitor $^{13}$, saponin $^{14,15}$, lectin $^{16}$, and more recently lunasin, a novel cancer preventive seed peptide bioactive peptides involved in the preventive and therapy of cancer ${ }^{6,16-18}$.

This study explores the use of Indonesian native plants, which was Grobogan soybean variety. Soybean meal is a co-product of soybean oil extraction, produced at industrial or laboratory scale. It has been known to have a high content of protein and amino acids. Soybean meal may be used as a source of various bioactive compounds ${ }^{19,20}$.

Inflammation bowel diseases especially in ulcerative colitis is an important risk factor in the development of colon carcinogenesis ${ }^{\mathbf{2 1}}$. In large intestinal inflammation showed reduced quantity and depletion of goblet cell. Reduction of goblet cells correlated with the severity and the extension of disease ${ }^{22,23}$. Depletion of goblet cells in the crypt is a beginning sign of colon carcinogenesis ${ }^{24}$. Inflammation can facilitate tumor promotion by activating the proliferation, encourage angiogenesis and finally to invasive colon cancer. Chronic inflammation of the large intestine has produced the genetic alteration that can develop into dysplasia and then cancer $^{23}$. The earliest stage in tumor development, the tumor cells will proliferate rapidly and showed a loss of growth control. Tumor cells require an adequate blood supply to provide nutrients for survival so that in the early stages of invasive cancer development stimulates the growth of new blood vessels (angiogenesis) ${ }^{\mathbf{2 5 2}}$.

An experimental colitis-associated colon carcinogenesis mouse model, chemically induced by azoxymethane and dextran sodium sulphate has been used often in colon cancer chemoprevention animal studies $^{27-29}$. AOM is a very potent carcinogen that causes colon cancer in rats and mice with high incidence. The resulting development of colon cancer resembles the pattern that occurs in humans ${ }^{27}$. DSS used to induce inflammation in experimental models of colitis-related colon cancer $^{28,30,31}$.

The present study was aimed to investigate the inhibitory activity of soybean in comparison with soybean meal extract on goblet cell count and micro vessel density in colitis-associated mouse colon carcinogenesis.

\section{Materials and Methods}

\section{Experimental Animals}

Experiments were performed on adolescent male Swiss Webster mice (body weight range 20-25 g), approximately 12 weeks of age, obtained from Animal Laboratories, National Institute of Health, Research and Development, Ministry of Health (Indonesia). Mice were maintained under controlled room temperature, humidity, and light (12/12 h light/dark cycle) and allowed ad libitum access to standard mouse chow and tap water. The mice were allowed to acclimate to these conditions for at least 7 days prior to inclusion in the experiments.

\section{Chemicals and botanical materials}

Lunasin standard was purchased from Polypeptide Laboratories France. Azoxymethane (AOM) and Dextran Sodium Sulfate(molecular weight $500.000 \mathrm{kDa}$ ) were purchased from Sigma-Aldrich Chemical Company. All other chemicals of analytical grade were obtained from Merck. Grobogan Soybean variety (Glycine max) was obtained from Indonesian Legumes and Tuber Crops Research Institute, Ministry of Agriculture (Indonesia). Soybean meal was purchased from local markets.

\section{Soybean and soybean meal extract preparation}

Grains of soybean and soybean meal were first dried to reduce the moisture content. The dried grains were milled then separated using a press machine in order to remove the oil. Residues from this process were 
pulverized into powder. The extract of residue and soybean meal was prepare b modifying methode ${ }^{32,33}$ as following: A kilogram point twenty-five both of residue and soybean meal were extracted once by phosphate buffer saline $(\mathrm{pH} \mathrm{7,4)}$ in a 5:1 ratio with an extraction time of sixty minutes. The extracting solution was filtered through cotton wool, then followed by the second filtration using filter paper. After filtering process, the PBS extract of soybean and soybean meal were dried by rotary evaporator at $40^{\circ} \mathrm{C}$. The dried extract was kept in the glass bottle and stored in the refrigerator until used for the preparation of experimental diets. About 175 grams of soybean and 230 grams soybean meal extract were obtained from 1,25 kilograms of soybean grains and soybean meal.

\section{Study design and carcinogen administration}

The experimental protocols were approved by the Ethics Committee of Faculty of Medicine, University of Indonesia (Indonesia). Experimental colon carcinogenesis ${ }^{\mathbf{2 8 , 3 1 , 3 4}}$ was induced by a single intra peritoneal injection $(10 \mathrm{mg} / \mathrm{kg})$ of a mutagenic agent, azoxymethane (AOM) and one week after AOM injection, all animals began to receive oral exposure ( $2 \%$ in drinking water) to a pro-inflammatory reagent, dextran sodium sulfate (DSS) for 7 consecutive days. Control animals received 0,9\% sterile saline and do not receive an oral exposure of DSS. The experimental design of this study is shown in Figure 1.

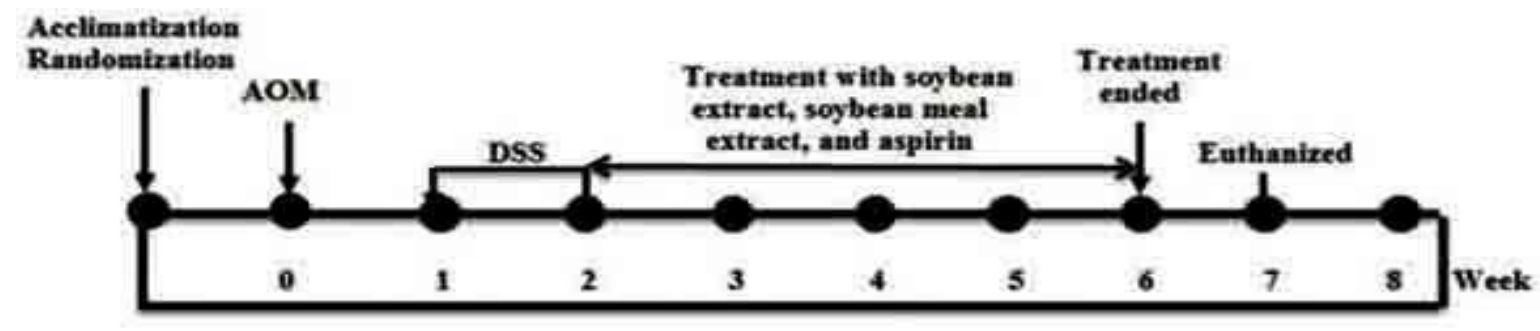

Figure 1. The experimental design for colitis-associated colon carcinogenesis

Animals were separated into nine groups ( $\mathrm{n}=3$ per group): control normal, colitis-associated colon carcinogenesis model, aspirin, soybean extract groups $(75,150,200 \mathrm{mg}$ ) and soybean meal extract groups (75, $150,200 \mathrm{mg}$ ). Animals were randomized and acclimatization one week before inducing by azoxymethane $(\mathrm{AOM})$ injection. At the beginning of experiments, all animals received a single intra peritoneal injection (10 $\mathrm{mg} / \mathrm{kg}$ ) of a mutagenic agent, azoxymethane (AOM) and one week after AOM injection, all animals began to receive oral exposure ( $2 \%$ in drinking water) to a pro-inflammatory reagent, dextran sodium sulfate (DSS) for 7 consecutive days. Control animals received $0,9 \%$ sterile saline and do not receive an oral exposure of DSS. After induce by AOM and DSS. The treatment group received aspirin solution, soybean extract $(75,150,200$ $\mathrm{mg}$ ) and soybean meal $(75,150,200 \mathrm{mg})$ daily for 4 weeks. One week after the end of treatment, all animals were sacrificed and the colons were collected.

In order to investigate Inhibitory activity of soybean in comparison with soybean meal extract on goblet cell counts and micro vessel density in colitis-associated mouse colon carcinogenesis, different doses of soybean extract, soybean meal extract and aspirin were administered by oral gavage up 4 weeks. Control animals received water by oral gavage one week after DSS administered. Body weight was measured every week during experimental. One week after the last day of the treatment, mice were sacrificed by intra peritoneal injection of 75-100 mg/kg ketamine combined with $10 \mathrm{mg} / \mathrm{kg}$ xylazine. Colon was harvested then prepared for histological analysis.

\section{Histological assessment}

Paraffin-embedded gut tissue samples were serially sectioned, and some sections were stained with hematoxylin and eosin. The stained sections were subsequently examined for histopathological changes.

\section{Histological examination of mucosa colon for goblet}

Count of goblet cells was quantified by counting the goblet cell number in ten randomly selected visual fields at mucosa colon region under $400 \mathrm{x}$ in colon sections from AOM and DSS-treated Swiss Webster mice. All slides were analyzed by double investigator who was blinded to the treatment groups. The comparison of 
goblet cells in all groups was performed by averaging out the numbers of goblet cells in ten random fields in each colonic section. Ten selected fields shown are representative of all stained sections.

\section{Histological examination of micro vessel density}

Micro vessel density (MVD) was quantified by counting micro vessel numbers in ten randomly selected visual fields at mucosa region under 400x in colon sections from AOM and DSS-treated Swiss Webster mice. Large vessels were excluded from analysis. The observer was blinded to treatment group. The comparison of MVD in all groups was performed by averaging out the numbers of micro vessels in ten random fields in each colonic section. Ten selected fields shown are representative of all stained sections.

\section{Statistical analyses}

All data are expressed as a mean \pm standard deviation. Data were analyzed using analyzed of variance (ANOVA) the followed by LSD's test to compare the differences between treatments. Differences were considered statistically significant for $\mathrm{p}<0,05$.

\section{Results}

Effect soybean and soybean meal extract on body weight: (Figure 2).

There was an increase body weight in all groups compared with the beginning of the experiment

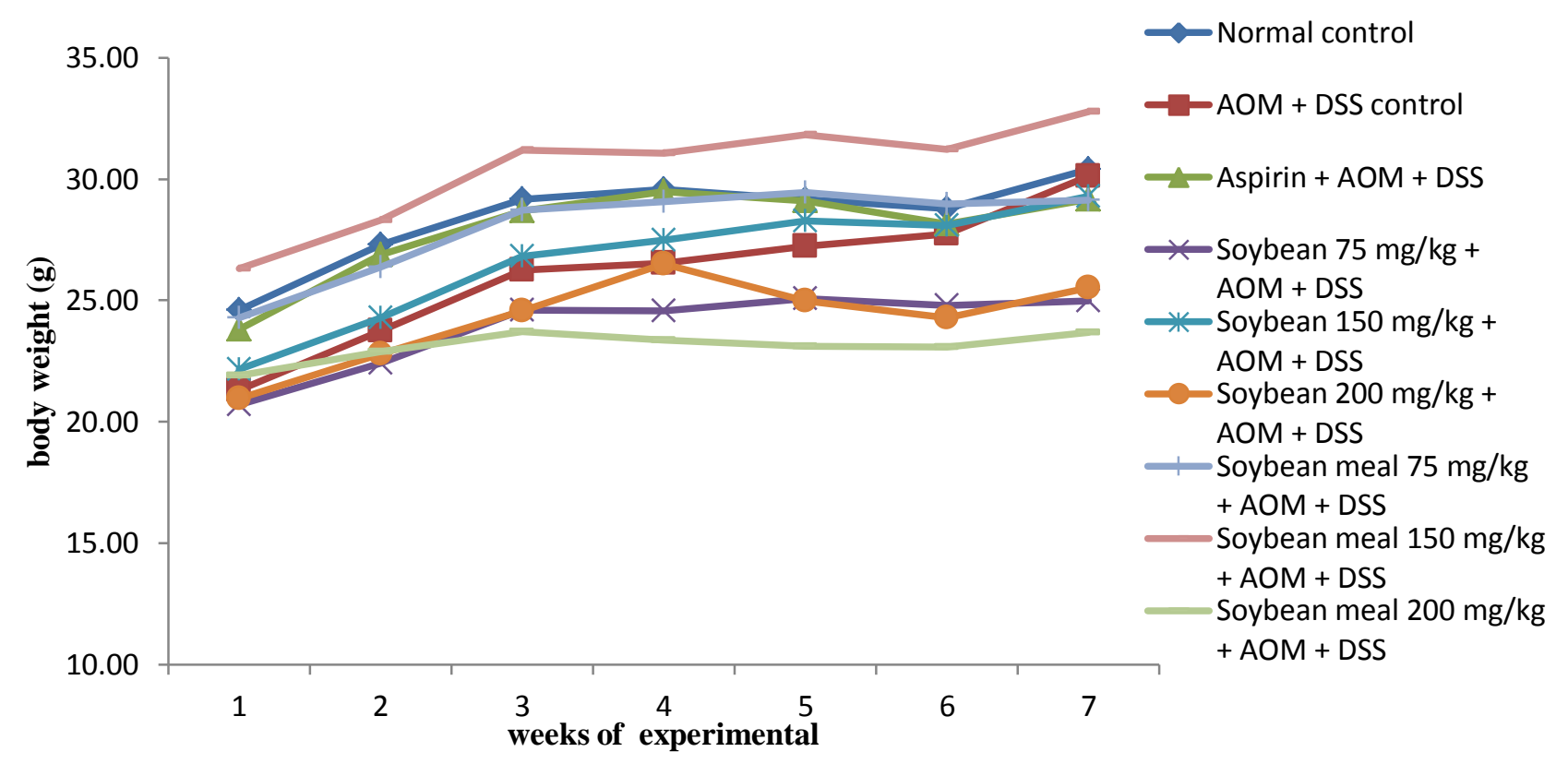

Figure 2.Body weights of mice. Body weights expressed as grams, where the interactive effects of duration of experimental (week) and the group were not significant (p>0,05) using Kruskall-Wallis test. Datas are reported as mean \pm standard deviation, $n=3$ /group.

\section{Effect soybean and soybean meal extract on goblet cells count:}

Effect of soybean and soybean meal extract on the histological of goblet cells in mice mucosa colon evaluated by hematoxylin and eosin staining 400xare shown in Figure. 3.

AOM/DSS induced colitis associated colon carcinogenesis resulted in a significant decrease in count of goblet cell $(84,77 \pm 14,78)$ in comparison to control group $(139,53 \pm 15,30)(p<0,05)$. After the administration of aspirin and different doses of soybean $(75,150,200 \mathrm{mg}$ ) and soybean meal extract (75 and $150 \mathrm{mg}$ ) to colitisassociated colon carcinogenesis in mice during 4 weeks a significant increase in count of goblet cells 
$(131,37 \pm 18,94 ; 138,03 \pm 22,59 ; 141,90 \pm 14,02 ; 134,10 \pm 22,05 ; 137,95 \pm 8,35 ;$ and $121,90 \pm 8,43$ vs $84,77 \pm 14,78$, respectively) $(\mathrm{p}<0,05)$ was observed (Table 1$)$.

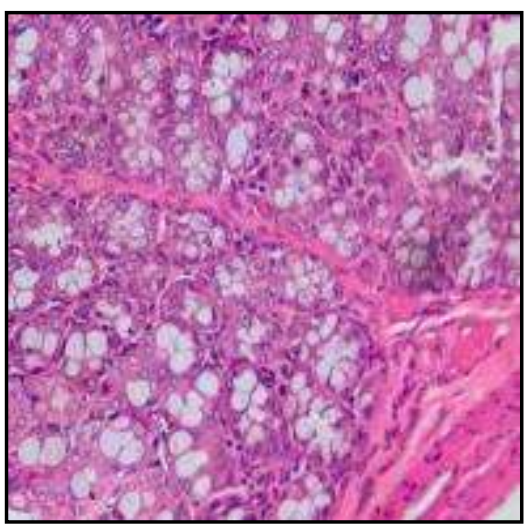

(a)

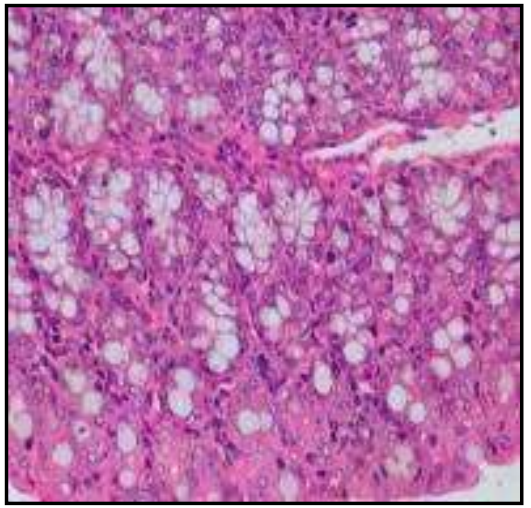

(d)

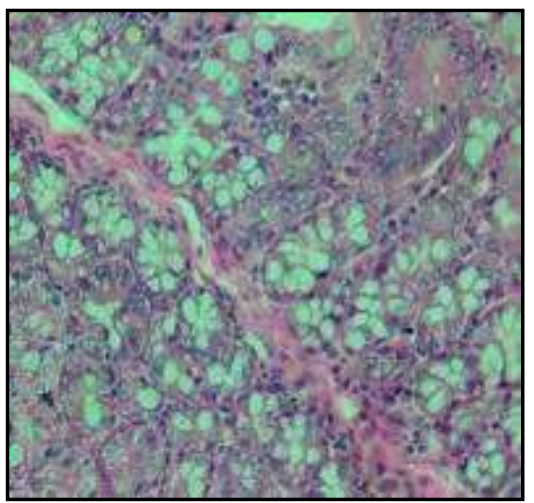

(g)

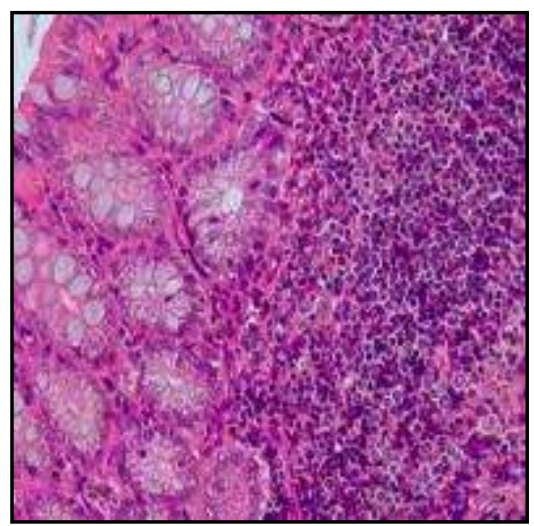

(b)

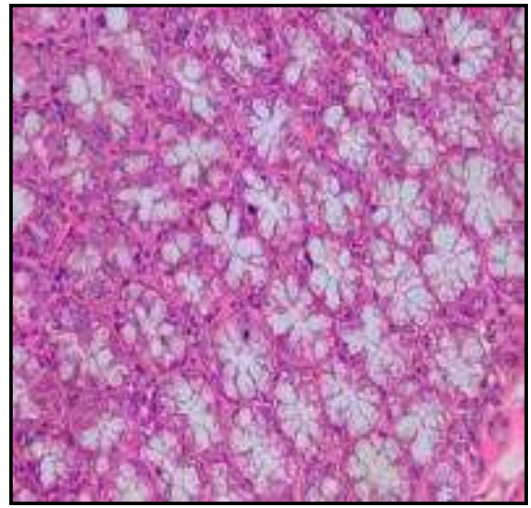

(e)

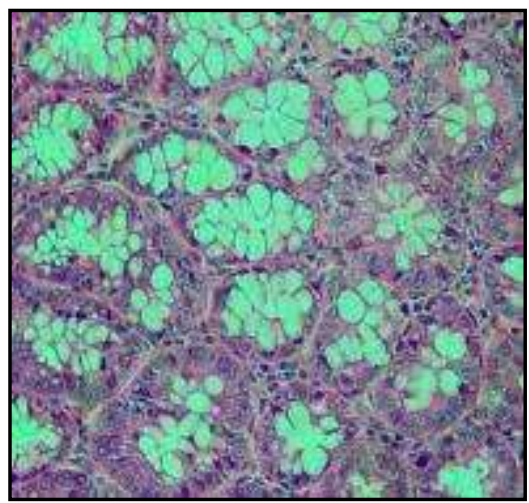

(h)

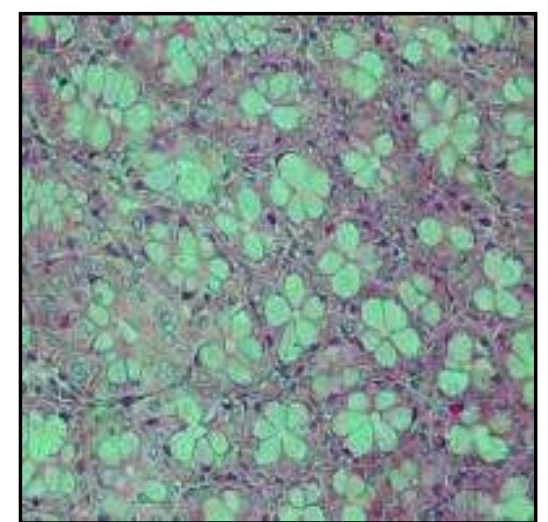

(c)

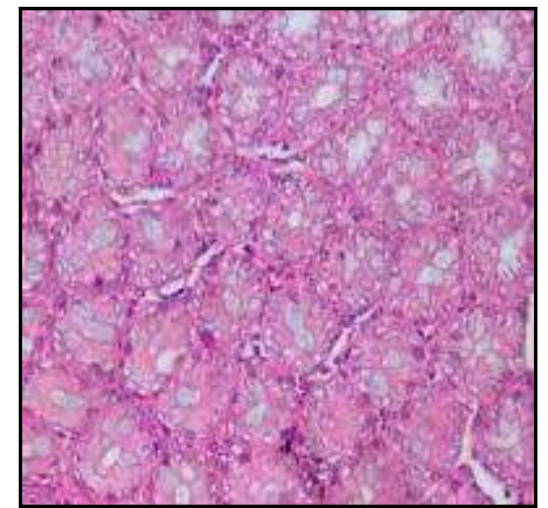

(f)

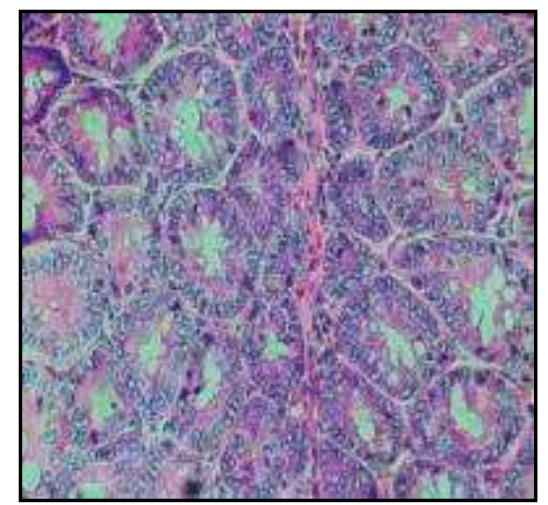

(i)

Figure 3.Effect of soybean and soybean meal extract on the histological of goblet cells in mice mucosa colon evaluated by hematoxylin and eosin staining 400x. (a) Control, (b) AOM/DSS Model, (c) Aspirin, (d) Soybean $75 \mathrm{mg} / \mathrm{kg}$, (e) Soybean $150 \mathrm{mg} / \mathrm{kg}$, (f) Soybean $200 \mathrm{mg} / \mathrm{kg}$, (g) Soybean meal $75 \mathrm{mg} / \mathrm{kg}$, (h) Soybean meal 150mg/kg, (i) Soybean meal $200 \mathrm{mg} / \mathrm{kg}$. 
Table 1.Effect of soybean and soybean meal extract on the goblet cell count after 4 weeks treatment

\begin{tabular}{|l|c|}
\hline \multicolumn{1}{|c|}{ Groups } & $\begin{array}{c}\text { Mean of goblet cell count in } \\
\text { ten fields visual }\end{array}$ \\
\hline Normal control & $139,53 \pm 15,30$ \\
\hline AOM + DSS control & $84,77 \pm 14,78^{\mathrm{a}}$ \\
\hline Aspirin + AOM + DSS control & $131,37 \pm 18,94^{\mathrm{b}}$ \\
\hline Soybean 75 mg/kg + AOM + DSS control & $138,03 \pm 22,59^{\mathrm{b}}$ \\
\hline Soybean $150 \mathrm{mg} / \mathrm{kg}+\mathrm{AOM}+\mathrm{DSS}$ control & $141,90 \pm 14,02^{\mathrm{b}}$ \\
\hline Soybean $200 \mathrm{mg} / \mathrm{kg}+\mathrm{AOM}+\mathrm{DSS}$ control & $134,10 \pm 22,05^{\mathrm{b}}$ \\
\hline Soybean meal $75 \mathrm{mg} / \mathrm{kg}+\mathrm{AOM}+\mathrm{DSS}$ control & $137,95 \pm 8,35^{\mathrm{b}}$ \\
\hline Soybean meal150 mg/kg + AOM + DSS control & $121,90 \pm 8,43^{\mathrm{b}}$ \\
\hline Soybean meal $200 \mathrm{mg} / \mathrm{kg}+\mathrm{AOM}+\mathrm{DSS}$ control & $101,10 \pm 14,99^{\mathrm{a}}$ \\
\hline
\end{tabular}

Data are expressed as mean \pm standard deviation; $n=3$. ANOVA followed by LSD's test $(p<0,05)$.

${ }^{a}$ statistically different from normal control mice; ${ }^{b}$ statistically different from AOM/DSS Model.

\section{Effect soybean and soybean meal extract on micro vessel density:}

Effect of soybean and soybean meal extract on the histological of micro vessel density in mice mucosa colon evaluated by hematoxylin and eosin staining 400xis shown in Figure. 4.

The number of micro vessel in AOM/DSS induced colitis associated colon carcinogenesis mice model $(11,90 \pm 0,92)$ shows a significant rise in comparison to control group $(4,50 \pm 0,89)(p<0,001)$. After the administration of aspirin and different doses of soybean $(75,150,200 \mathrm{mg}$ ) to colitis-associated colon carcinogenesis in mice during 4 weeks showed a significant decrease in the number of micro vessel $(7,67 \pm 0,64$; $5,87 \pm 0,51 ; 4,97 \pm 1,25$ and $4,77 \pm 1,30$, vs $7,67 \pm 0,64$ respectively) ( $<<0,001)$ was observed (Table 2 ). Soybean meal doses $(75,150,200 \mathrm{mg})$ showed a decrease in the number of micro vessel in comparison to colitisassociated colon carcinogenesis in mouse model but it was not statistically significant ( $p>0,001)$.

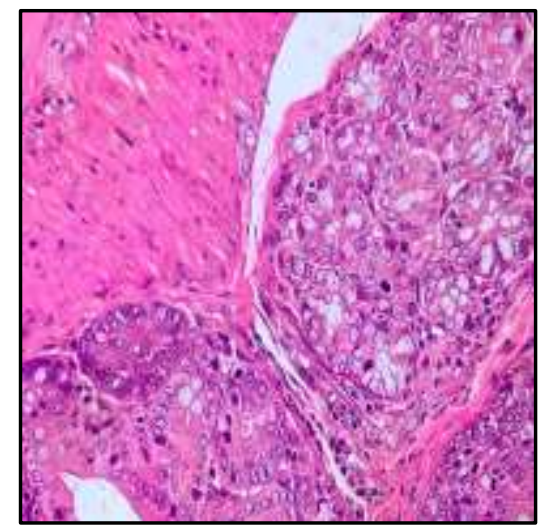

(a)

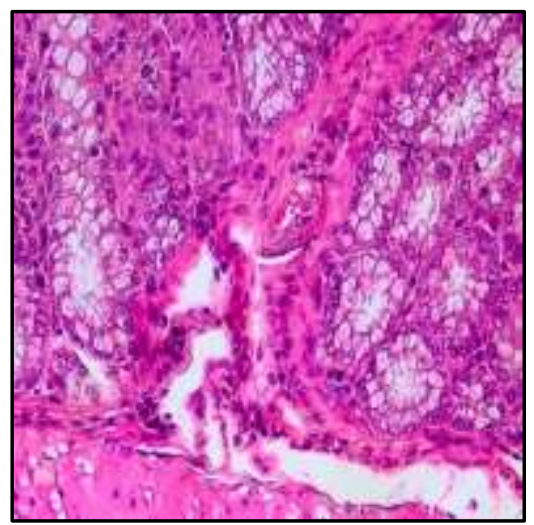

(b)

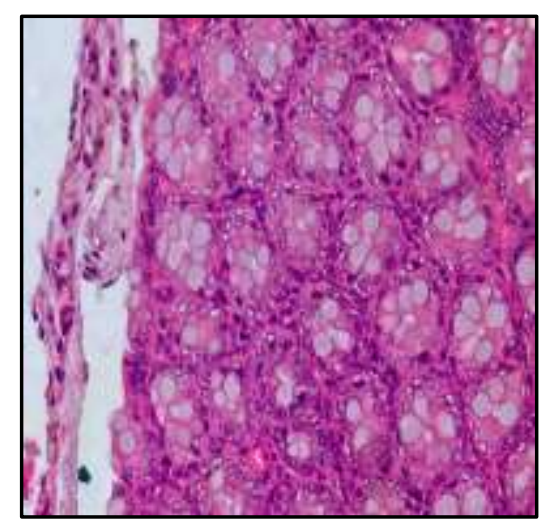

(c) 


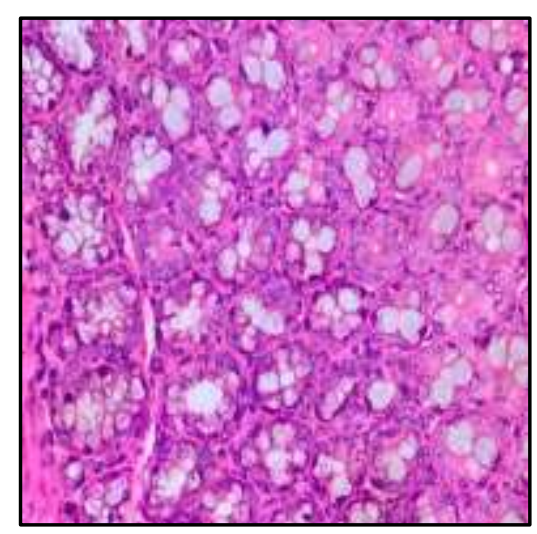

(d)

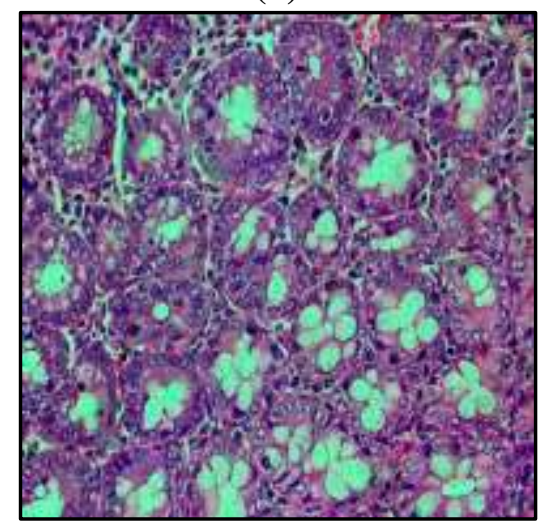

(g)

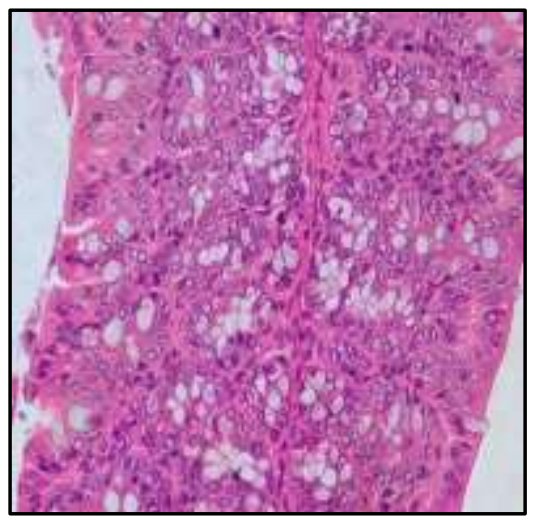

(e)

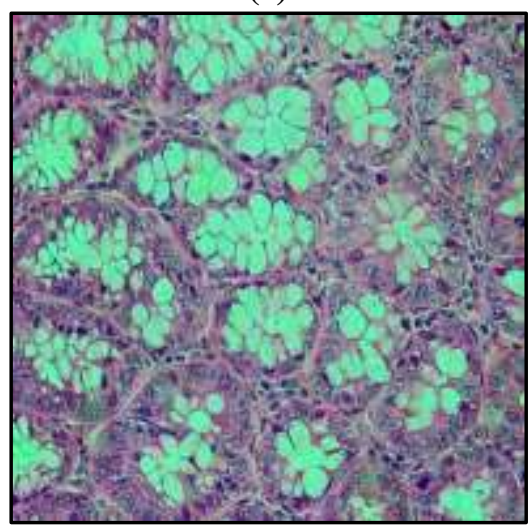

(h)

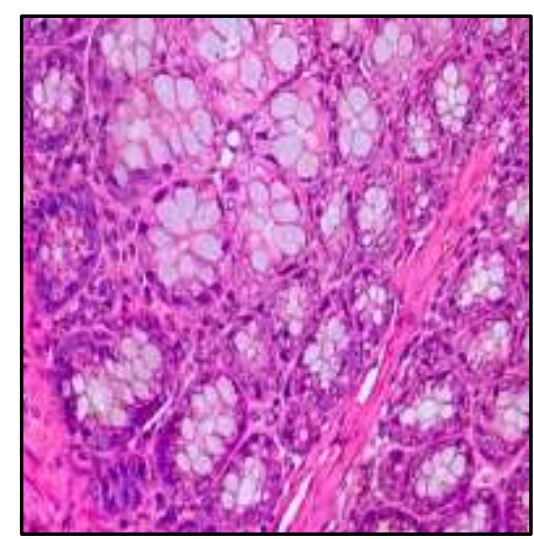

(f)

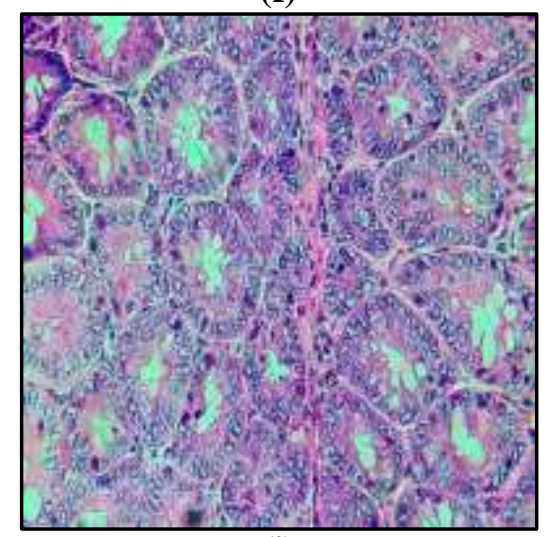

(i)

Figure 4.Effect of soybean and soybean meal extract on the histological of micro vesselon mice mucosa colon evaluated by hematoxylin and eosin staining 400x. (a) Control, (b) AOM/DSS Model, (c) Aspirin, (d) Soybean 75, (e) Soybean 150, (f) Soybean 200, (g) Soybean meal 75, (h) Soybean meal 150, and (i) Soybean meal 200.

Table 2. Effect of soybean and soybean meal extract on the micro vessel density after 4 weeks treatment

\begin{tabular}{|l|c|}
\hline \multicolumn{1}{|c|}{ Groups } & $\begin{array}{c}\text { Mean of micro vessel density } \\
\text { in ten fields visual }\end{array}$ \\
\hline Normal control & $4,50 \pm 0,89$ \\
\hline AOM + DSS control & $11,90 \pm 0,92^{\mathrm{a}}$ \\
\hline Aspirin + AOM + DSS control & $7,67 \pm 0,64^{\mathrm{ab}}$ \\
\hline Soybean $75 \mathrm{mg} / \mathrm{kg}+\mathrm{AOM}+\mathrm{DSS}$ control & $5,87 \pm 0,51^{\mathrm{b}}$ \\
\hline Soybean $150 \mathrm{mg} / \mathrm{kg}+\mathrm{AOM}+\mathrm{DSS}$ control & $4,97 \pm 1,25^{\mathrm{b}}$ \\
\hline Soybean $200 \mathrm{mg} / \mathrm{kg}+\mathrm{AOM}+\mathrm{DSS}$ control & $4,77 \pm 1,30^{\mathrm{b}}$ \\
\hline Soybean meal $75 \mathrm{mg} / \mathrm{kg}+\mathrm{AOM}+\mathrm{DSS}$ control & $10,30 \pm 0,20^{\mathrm{a}}$ \\
\hline Soybean meal150 mg/kg + AOM + DSS control & $8,53 \pm 0,40^{\mathrm{ab}}$ \\
\hline Soybean meal $200 \mathrm{mg} / \mathrm{kg}+\mathrm{AOM}+$ DSS control & $9,57 \pm 2,55^{\mathrm{ab}}$ \\
\hline
\end{tabular}

Data are expressed as mean \pm standard deviation; $n=3$. ANOVA followed by LSD's test ( $<<0,001)$. 'statistically different from control mice; ${ }^{b}$ statistically different from AOM/DSS Model.

\section{Discussion}

Colon carcinogenesis has been shown to be a multistep process of genetic and phenotypic alterations of normal bowel epithelium structure and function leading to unregulated cell growth, proliferation, and tumor development ${ }^{36}$. Ulcerative colitis are an important risk factor for the development of colon cancer. Several reports suggest that the rate of colon cancer is increasing in ulcerative colitis ${ }^{\mathbf{2 1 , 3 7 , 3 8}}$. Aspirin has been associated 
with a lower risk of colon cancer. Several decades of research have provided considerable evidence demonstrating its potential for the prevention of cancer, particularly colon cancer ${ }^{39-41}$. AOM and DSS have often been used in colon cancer animal studies. In this study, we used the AOM/DSS mouse model to mimic the inflamed colon and carcinogenesis conditions in humans ${ }^{27-29,42}$.

In ulcerative colitis, there are reduced in the number of goblet cells (goblet cell depletion) and thinner colonic mucus layer. Goblet cells are largely responsible for secreting components of the intestinal mucosal barrier and represent a major cellular component of the innate defense system Goblet cell clearly marked the severity of intestinal inflammation ${ }^{22,43}$. The number of goblet cell is known decreased obviously in aberrant crypt foci, an earlier marker of colon carcinogenesis ${ }^{25,44,45}$.

Tumor cells and surrounding tissues secrete factors that stimulate the growth of new blood vessel. Previous studies showed that the micro vessel density occurs in the early colon carcinogenesis and was accentuated at the bottom of crypt ${ }^{46}$. MVD is a well-established technique to assess angiogenesis in colon cancer and has prognostic significance ${ }^{47}$. Neo-angiogenesis have potential implications as a target for chemoprevention $^{25,46}$.

The results of the present study indicate that soybean extract significantly inhibits both the reduction in the number of goblet cell and micro vessel density in colitis-associated colon carcinogenesis mouse model. The soybean meal extract significantly inhibits the reduction in the number of goblet cell but not in micro vessel density. However, the soybean meals were obtained from local market unclear origin. This result supports the previous meta-analyses study that the consumption of soybean is associated with lower colon cancer risk in human $^{\text {9,11 }}$. The Previous study showed that raw soybean has a protective effect against early carcinogenesis ${ }^{48}$. Contents of phytochemicals in soybean that involved in therapeutic and preventive cancer are protease inhibitor, phytic acid, phytosterol, saponin, isoflavone, lectin, and lunasin ${ }^{16-18}$. Lunasin selectively causes apoptosis, mostly in cells undergoing the transformation, by preventing histone acetylation ${ }^{49}$. Lunasin also exerts antiinflammatory properties that play an important factor in tumor proggression ${ }^{32,50}$. The previous study provide evidence that soy isoflavonegenistein and soybean based diet were able to reduce the number of blood vessel in mouse models of melanoma and breast cancer ${ }^{51}$ Study the chemopreventive ability against late carcinogenesis may allow for a clearer chemopreventive effect of Indonesian soybean. Other bio-markers are needed to fully elucidate the complex mechanism of Indonesian soybean to explore the potential role of Indonesian soybean in colon cancer chemoprevention.

Currently, there a few reports on the effect of Indonesian soybean in experimental colitis-associated colon carcinogenesis. Data reported in this study suggested that Indonesian soybean as a candidate of botanicalbased colitis-associated colon cancer chemoprevention should be further investigated for its safety and efficacy and potential clinical applications.

In conclusion,Indonesian soybean and soybean meal extract may have inhibitory activityin colitisassociated colon carcinogenesis through inhibiting reduction in the number of goblet cell and micro vessel density. Indonesian soybean may have Inhibitory activity better than soybean meal on early colon carcinogenesis.

\section{References}

1. International Agency for Research on Cancer, World Cancer Report2014, WHO Press, Geneva, 2014.

2. M.S.H. Wahyuningsih, The potential development of Indonesian herbal medicine for cancer therapy. In: Inauguration Speech, University of Gadjah Mada,Yogyakarta, 2010.

3. B. Hernández-Ledesma, C.C. Hsieh and B.O. de Lumen, Protein Pept. Lett., 20, 424 (2013).

4. J. Liu, S.H. Jia, M. Kirberger and N. Chen, Eur. Rev. Med. Pharmacol. Sci., 18, 2070 (2014).

5. B. Hernández-Ledesma, C.C. Hsieh and B.O. de Lumen, Peptides, 30, 426 (2009); doi:10.1016/j.peptides.2008.11.002.

6. B. Hernández-Ledesma, B.O. de Lumen, Perspectives in Med. Chem., 2008, 75 (2008).

7. B.O. Lumen, Nutr. Rev., 63, 16 (2005); doi:10.1111/j.1753-4887.2005.tb00106.x.

8. T.K. Lim, Glycine max. In: Edible Medicinal and Non Medicinal Plants, Vol. 2, Springer, Netherland, pp. 634-714 (2012).

9. L. Yan, E.L. Spitznagel and M.C. Bosland, Cancer Epidemiol. Biomarkers Prev., 19, 148 (2010); doi:10.1158/1055-9965.EPI-09-0856. 
10. K. Toyomura and S. Kono, Asian Pac. J. Cancer Prev., 3, 125 (2012).

11. B. Zhu, Y. Sun, L. Qi, R. Zhong and X. Miao, Sci. Rep., 5, 87 (2015).

12. W.K. Min, H.Y. Sung and Y.S. Choi, J. Med. Food, 13, 495 (2010); doi:10.1089/jmf.2009.1208.

13. A. Clemente, F.J. Moreno, M.C. Marín-Manzano, E. Jiménez and C. Domoney, Mol. Nutr. Food Res., 54, 396 (2010); doi:10.1002/mnfr.200900122.

14. D.M. Gurfinkel and A.V. Rao, Nutr. Cancer, 47, 24 (2003); doi:10.1207/s15327914nc4701_3.

15. C.Y. Tsai, Y.H. Chen, Y.W. Chien, W.H. Huang and S.H. Lin, World J. Gastroenterol., 16, 3371 (2010); doi:10.3748/wjg.v16.i27.3371.

16. E.G. de Mejia, T. Bradford and C. Hasler, Nutr. Rev., 61, 239 (2003); doi:10.1301/nr.2003.jul.239-246.

17. M. Messina and S. Barnes, J. Natl. Cancer Inst., 83, 541 (1991); doi:10.1093/jnci/83.8.541.

18. B.O. de Lumen and A.F. Galvez, Soybean protein nutraceuticals, United States Patent, No. 6,391,848, B1, May 21, 2002.

19. F.D.O. Silva and D. Perrone, Lebensm. Wiss. Technol., 63, 992 (2015); doi:10.1016/j.lwt.2015.04.032.

20. T. Banaszkiewicz, Soybean and Nutrition, pp. 1-21 (2011).

21. J. Terzić, S. Grivennikov, E. Karin and M. Karin, Gastroenterology, 138, 2101 (2010); doi:10.1053/j.gastro.2010.01.058.

22. U. Erben, C. Loddenkemper, K. Doerfel, S. Spieckermann, D. Haller, M.M. Heimesaat, M. Zeitz, B. Siegmund and A.A. Kuhl, Int. J. Clin. Exp. Pathol., 7, 4557 (2014).

23. A.E. Dorofeyev, I.V. Vasilenko, O.A. Rassokhina and R.B. Kondratiuk, Gastroenterol. Res. Practice, Article ID 431231 (2013).

24. T. Tanaka, J. Carcinog., 8, 5 (2009).

25. D. Hanahan and R.A. Weinberg, Cell, 144, 646 (2011); doi:10.1016/j.cell.2011.02.013.

26. B. Albert, A. Johnson, J. Lewis, D. Morgan, M. Raff, K. Roberts and P. Walter, Molecular Biology of The Cell, 6th Edition, Garland Science, United States of America, pp. 1091-1144 (2015).

27. R. Suzuki, H. Kohno, S. Sugie, H. Nakagama and T. Tanaka, Carcinogenesis, 27, 162 (2005); doi:10.1093/carcin/bgi205.

28. T. Tanaka, H. Kohno, R. Suzuki, Y. Yamada, S. Sugie and H. Mori, Cancer Sci., 94, 965 (2003); doi:10.1111/j.1349-7006.2003.tb01386.x.

29. C. Yu, X.D. Wen, Z. Zhang, C.F. Zhang, X.H. Wu, A. Martin, W. Du, T.C. He, C.Z. Wang and C.S. Yuan, J. Ginseng Res., 39, 14 (2015); doi:10.1016/j.jgr.2014.07.001.

30. R. Suzuki, H. Kohno, S. Sugie and T. Tanaka, Histol. Histopathol., 20, 483 (2005).

31. M.L. Clapper, H.S. Cooper and W.C.L. Chang, Acta Pharmacol. Sin., 28, 1450 (2007); doi:10.1111/j.1745-7254.2007.00695.x.

32. V.P. Dia, W. Wang, V.L. Oh, B.O. Lumen and E.G. de Mejia, Food Chem., 114, 108 (2009); doi:10.1016/j.foodchem.2008.09.023.

33. L.E. Seber, B.W. Barmett, E.J. McCornnell, S.D. Hume, J. Cai, K. Boles and K.R. Davis, PLoS One, 7, e35409 (2012).

34. M.L. Clapper, M.A. Gary, R.A. Coudry, S. Litwin, W.C.L. Chang, K. Devarajan, R.A. Lubet and H.S. Cooper, Inflamm. Bowel Dis., 14, 1341 (2008); doi:10.1002/ibd.20489.

35. H.J. Jeong, J.B. Jeong, D.S. Kim and B.O. de Lumen, J. Agric. Food Chem., 55, 632 (2007); doi:10.1021/jf062405u.

36. B. Wells, J. Dipiro, T. Schwinghammer and C. Dipiro, Colorectal Cancer, In: Pharmacotherapy Handbook, Mc GrawHill, New York, pp. 689-699 (2009).

37. S.I. Grivennikov, Semin. Immunopathol., 35, 229 (2013); doi:10.1007/s00281-012-0352-6.

38. T. Kinugasa and Y. Akagi, World J. Gastrointest. Oncol., 8, 351 (2016); doi:10.4251/wjgo.v8.i4.351.

39. D.A. Drew, Y. Cao and A.T. Chan, Nat. Rev. Cancer, 16, 173 (2016); doi:10.1038/nrc.2016.4.

40. A.T. Chan, S. Ogino and C.S. Fuchs, N. Engl. J. Med., 356, 2131 (2007); doi:10.1056/NEJMoa067208.

41. X. Garcia-Albeniz and A.T. Chan, Best Pract. Res. Clin. Gastroenterol., 25, 461 (2011); doi:10.1016/j.bpg.2011.10.015.

42. D.W. Rosenberg, C. Giardina and T. Tanaka, Carcinogenesis, 30, 183 (2008); doi:10.1093/carcin/bgn267.

43. H.A. McCauley and G. Guasch, Trends Mol. Med., 21, 492 (2015); doi:10.1016/j.molmed.2015.06.003.

44. L. Cheng and M.D. Lai, World J. Gastroenterol., 9, 2642 (2003); doi:10.3748/wjg.v9.i12.2642.

45. A.A. Almagrami, M.A. Alshawsh, R. Saif-Ali, A. Shwter, S.D. Salem and M.A. Abdulla, PLoS One, 9, e96004 (2014); doi:10.1371/journal.pone.0096004. 
46. A.K. Tiwari, S.E. Crawford, A. Radosevich, R.K. Wali, Y. Stypula, D.P. Kunte, N. Mutyal, S. Ruderman, A. Gomes, M.L. Cornwell, M.D.L. Cruz, J. Brasky, T.P. Gibson, V. Backman and H.K. Roy, Cancer Lett., 306, 205 (2011); doi:10.1016/j.canlet.2011.03.008.

47. T. Aotake, C.D. Lu, Y. Chiba, R. Muraoka and N. Tanigawa, Clin. Cancer Res., 5, 135 (1999).

48. M.A.I.E. Faris, H.R. Takruri, M.S. Shomaf and Y.K. Bustanji, Nutr. Res., 29, 355 (2009); doi:10.1016/j.nutres.2009.05.005.

49. A.F. Galvez, N. Chen, J. Macasieb and B.O. De Lumen, Cancer Res., 61, 7473 (2001).

50. L.M. Coussens and Z. Werb, Nature, 420, 860 (2002); doi:10.1038/nature01322.

51. H.G. Farina, M. Pomies, D.F. Alonso and D.E. Gomez, Oncol. Rep., 16, 885 (2006). 